\title{
Radiocarbon and Oxidizable Carbon Ratio Dates from Archaeological Sites in East Texas, Part II
}

Timothy K. Perttula

Heritage Research Center, Stephen F. Austin State University

Follow this and additional works at: https://scholarworks.sfasu.edu/ita

Part of the American Material Culture Commons, Archaeological Anthropology Commons, Environmental Studies Commons, Other American Studies Commons, Other Arts and Humanities Commons, Other History of Art, Architecture, and Archaeology Commons, and the United States History Commons

Tell us how this article helped you.

This Article is brought to you for free and open access by the Center for Regional Heritage Research at SFA ScholarWorks. It has been accepted for inclusion in Index of Texas Archaeology: Open Access Gray Literature from the Lone Star State by an authorized editor of SFA ScholarWorks. For more information, please contact cdsscholarworks@sfasu.edu. 


\section{Radiocarbon and Oxidizable Carbon Ratio Dates from Archaeological Sites in}

East Texas, Part II

\section{Creative Commons License}

\section{(c) (1) \&}

This work is licensed under a Creative Commons Attribution-NonCommercial 4.0 International License 


\title{
RADIOCARBON AND OXIDIZABLE CARBON RATIO DATES FROM ARCHAEOLOGICAL SITES IN EAST TEXAS, PART II
}

\author{
Timothy K. Perttula
}

\begin{abstract}
This paper presents a second compilation of recently obtained radiocarbon and oxidizable carbon ratio dates obtained from archaeological sites in East Texas. An analysis of the age ranges in the more than 585 dates from East Texas archaeological sites indicate that most pertain to prehistoric and protohistoric Caddoan Indian occupations, particularly the Early (A.D. 1000-1200) and Middle Caddoan (A.D. 1200-1400) periods when prehistoric Caddoan settlements were widely distributed throughout the region.
\end{abstract}

\section{INTRODUCTION}

More than 585 radiocarbon and oxidizable carbon ratio (OCR) dates have been obtained from archaeological sites in East Texas in the last 40 years or so (the OCR dates have only been obtained since 1996, however). This is a large and important chronological data base on prehistoric and historic Native American occupations in the region, but it has been a data base difficult to use because much of the information on the dates, and the archaeological sites from which the dates were obtained, has not been widely accessible until now. In this paper, I present a compendium of some 61 newly available radiocarbon and OCR dates from East Texas (Tables 1 and 2); previously, Perttula (1998a) published in Radiocarbon a compilation of 526 radiocarbon and OCR dates that was current through July 1, 1997.

This second compilation is based primarily on unpublished information from East Texas archaeological investigations, particularly cultural resource management excavations conducted under the auspices of the Antiquities Code of Texas and Section 106 of the National Historic Preservation Act. Perttula's (1998a) earlier work relied heavily on Dee Ann Story's (1990a) published compilation as the one key resource utilized to build the data base presented there, along with the extensive radiocarbon data base from investigations at Cooper Lake in the Sulphur River basin (see Fields et al. 1997: Appendix B). The results of the many additional samples included here were gathered from archaeological technical reports on file at the Division of Archeology at the Texas Historical Commission (Austin, Texas), or provided by researchers working in East Texas (see Acknowledgments).

Data on the newer radiocarbon assays are included in Table 1, namely the assay number, the provenience, the raw radiocarbon age, the delta $13 \mathrm{C}$ values, the corrected radiocarbon age, the calibrated age range, and the relative area under the probability distribution for onesigma calibrated ages. The radiocarbon assays are uniformly corrected (for isotopic fractionation) and calibrated at a 20-year interval scale for calendric dates using CALIB 3.03c, Test 10 (Stuiver and Reimer 1993a, 1993b). Assays that lacked delta 13C values use the value estimates for fractionation correction suggested by Stuiver and Reimer (1993b:Table 1): $-25 \mathrm{o} / \mathrm{oo}$ for nutshells and charcoal, and $-10 \mathrm{o} / 00$ for charred maize.

As of the writing of this paper, 16 archaeological sites in East Texas have OCR dates: 41BW553 (Largent et al. 1997), Underwood (41CP230), Knight's Bluff (41CS14), 41HO54, Hargrove Lake (41HO150), 41 HO184 (Perttula and Prikryl 1997); 41HS407; Fasken (41RR14), Redwine (41SM193; Mark Walters, 1997 personal communication), 
41TN110, 41TN113 (David H. Jurney, 1997 personal communication); 41TT653, 41TT670, Tom Moore (41PN149), Rookery Ridge (4IUR133; see Parsons 1998); and the Camp Joy Mound (41UR144) (Perttula et al. 1997a, 1997b). OCR dating is a new dating procedure developed by the Archaeology Consulting Team, Inc. (Essex Junction, Vermont) for obtaining absolute dates on charcoal and soil humic materials from features. The procedure measures the relationship between the total carbon and the readily oxidizable carbon in a soil sample, with the ratio between the two--the oxidizable carbon ratio-apparently following a linear progression through time. Frink (1992, 1994, 1995; see also Kindall 1997) discusses the OCR dating procedure in detail. Table 2 provides data on the 48 available OCR dates in East Texas, with information on assay number, the provenience, the calculated OCR date in years before present, the confidence interval, and the final, rounded date as suggested by Frink (1996 personal communication). As OCR dating is a new dating method, its reliability and validity (in the sense of Ramenofsky and Steffen 1998:8-10) as an absolute estimate of time has not been fully established, and more OCR samples are warranted (particularly from a variety of contexts where radiocarbon dates have also been obtained) to assess how the influencing factors of sample depth, mean temperature, average annual rainfall, mean soil texture, soil acidity, and percent of carbon (Frink 1994) in the OCR procedure work for samples from East Texas (Douglas S. Frink, August 5, 1998 personal communication).

\section{DATA BASE}

Currently, there are 538 available radiocarbon dates and 49 OCR dates from 118 prehistoric archaeological sites in 24 East Texas counties (Table 3). However, most of the archaeological sites only have between one and three dates (see Tables 1 and 2), with very few of the sites having more than a total of 15 radiocarbon and/or OCR assays. The latter sites include George C. Davis (41CE19, n=130; see Story 1990a, 1997, 1998; Story and Valastro 1977); Oak Hill Village (41RK214; $n=34$; Robert Rogers, 1998 personal communication; see also Cruse 1995); Spider Knoll (41DT1I, n=23; see Fields et al. 1994a); Arnold (41HP102, n=18; Doehner and Larson 1978); Hurricane Hill (41HP106, $\mathrm{n}=18$; see Perttula 1998); and Mockingbird (41TT550, $\mathrm{n}=17$; see Perttula et al. 1998); three of the sites are in the Cooper Lake project area in Delta and Hopkins counties (Fields et al. 1997).

Table 3. County Statistics on Sites with Dates and Number of Dates

\begin{tabular}{|c|c|c|c|c|}
\hline County & $\begin{array}{l}\text { No. of Sites } \\
\text { with } \\
\text { Radiocarbon } \\
\text { Dates }\end{array}$ & $\begin{array}{c}\text { No. of Radiocarbon } \\
\text { Dates }\end{array}$ & $\begin{array}{l}\text { No. of Sites } \\
\text { with OCR } \\
\text { Dates }\end{array}$ & $\begin{array}{l}\text { No. of } \\
\text { OCR } \\
\text { Dates }\end{array}$ \\
\hline
\end{tabular}

$\begin{array}{lll}\text { Anderson } & 3 & 5 \\ \text { Bowie } & 3 & 10 \\ \text { Camp } & 3 & 5 \\ \text { Cass } & 5 & 12 \\ \text { Cherokee } & 1 & 130 \\ \text { Delta } & 15 & 84 \\ \text { Harrison } & 3 & 6 \\ \text { Henderson } & 4 & 11 \\ \text { Houston } & - & - \\ \text { Hopkins } & 10 & 67\end{array}$


Table 3. County Statistics on Sites with Dates and Number of Dates, cont.

\begin{tabular}{lllll}
\hline County & $\begin{array}{l}\text { No. of Sites } \\
\text { with } \\
\text { Radiocarbon } \\
\text { Dates }\end{array}$ & $\begin{array}{c}\text { No. of Radiocarbon } \\
\text { Dates }\end{array}$ & $\begin{array}{l}\text { No. of Sites } \\
\text { with OCR } \\
\text { Dates }\end{array}$ & $\begin{array}{l}\text { No. of } \\
\text { OCR } \\
\text { Dates }\end{array}$ \\
\hline Jasper & 1 & & - & - \\
Lamar & 2 & 3 & - & - \\
Morris & 1 & 20 & - & - \\
Nacogdoches & 3 & 5 & - & - \\
Panola & - & 15 & 1 & 3 \\
Red River & 5 & - & 1 & 4 \\
Rusk & 5 & 23 & - & - \\
Sabine & 2 & 43 & - & - \\
Shelby & 3 & 2 & 1 & 1 \\
Smith & 2 & 6 & 2 & 12 \\
Titus & 14 & 2 & 2 & 2 \\
Trinity & - & 50 & 2 & - \\
Upshur & 8 & - & - & - \\
Wood & 9 & 17 & & 49 \\
\hline Totals & 102 & 22 & 16 & \\
\hline
\end{tabular}

The counties with the highest numbers of sites with radiocarbon dates (Delta, Titus, and Hopkins) all have been the scene of intensive cultural resource management-related archaeological investigations in the 1980s and 1990s. The same situation basically exists for the counties with the highest numbers of radiocarbon (and OCR) dates, with the exception of Cherokee County, where the 130 dates from the George C. Davis site were obtained principally from intensive investigations of mound and village areas in 1968-1970 (Story 1997, 1998).

The great majority of the East Texas radiocarbon dates have been obtained from Late Archaic, Woodland, and Formative-Late Caddoan period sites (Figure 1). Less than 1.3 percent of the dates are associated with either Paleoindian (ca. 10,000 B.C.-6000 B.C.) or Early/Middle Archaic (ca. 6000 B.C.-2000 B.C.) period occupations, and less than 0.5 percent may be associated with the post-A.D. 1680 Caddoan occupation of the region. The largest number of radiocarbon dates $(\mathrm{n}=153)$ fall in the Middle Caddoan period (ca. A.D. 1200-1400), followed by the Early Caddoan period (ca. A.D. 1000-1200) ( $\mathrm{n}=101$; see Figure 1).

More than 80 percent of the radiocarbon dates pertain to occupations at prehistoric and protohistoric Caddoan sites in East Texas (see Figure 1). Relative to the 200 year periods defined by Story (1990b:334) for the Caddoan tradition, radiocarbon dates associated with the Early and Middle Caddoan periods comprise 63.5 percent of the total radiocarbon date sample, followed by those falling in the Late Caddoan (A.D. 1400-1680) (19.3 percent) and Formative Caddoan (A.D. 800-1000) (16.8 percent) periods (Figure 2).

At a slightly finer scale, using calibrated ages and age mid-points of 1-sigma calibrated age ranges, the largest number of Caddoan radiocarbon dates fall within the A.D. 1201-1300 


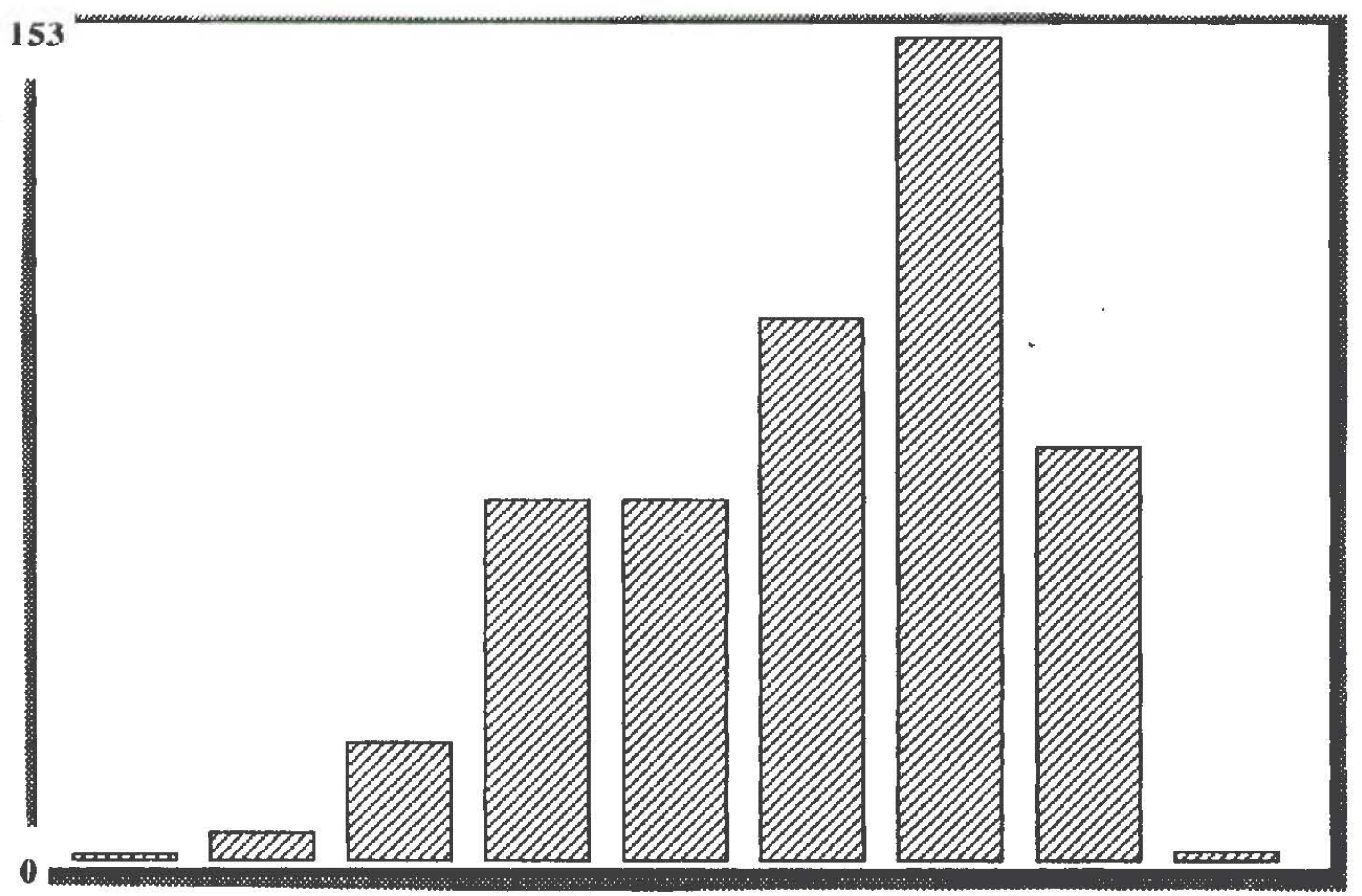

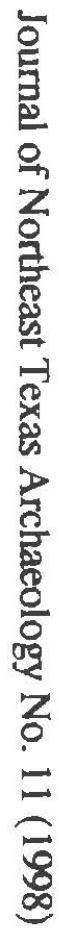

Figure 1. Number of Radiocarbon Dates for the Paleoindian, Early/Middle Archaic, Late Archaic, Woodland, Formative Caddoan, Early Caddoan, Middle Caddoan, Late Caddoan, and Historic Caddoan periods. 


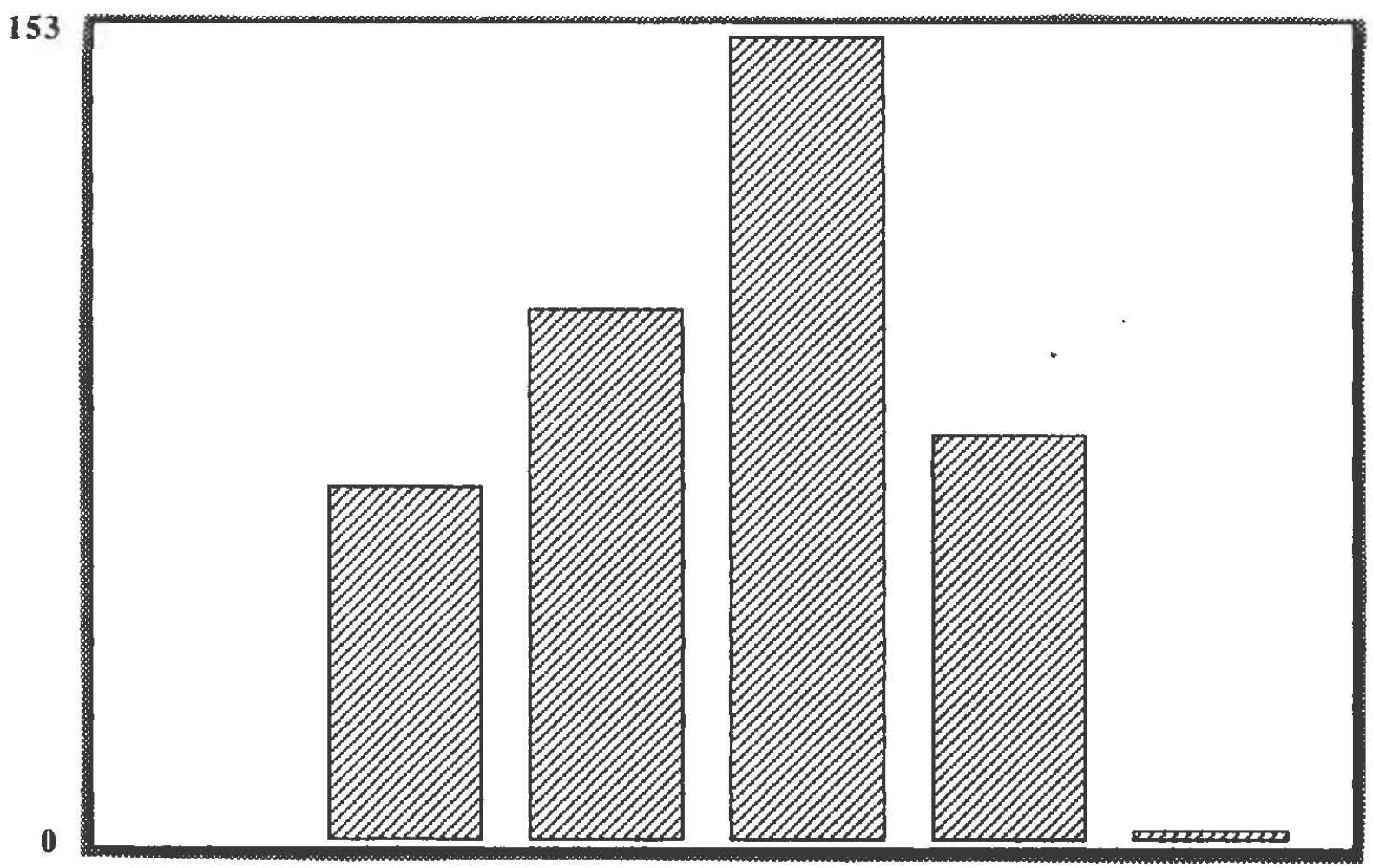

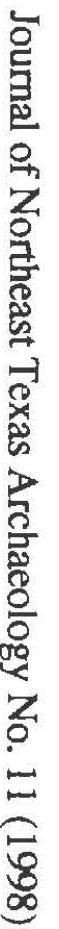

Figure 2. Number of Radiocarbon Dates for the Formative Caddoan through Historic Caddoan Periods. 
interval (Figure 3). While the number of dates in this period of time is probably inflated to some degree by the extensive series of dates from the George C. Davis site (see Table 1), nevertheless it does appear to be the case that Middle Caddoan period occupations are rather commonplace throughout much of East Texas (see Middlebrook and Perttula 1997). In fact, this period probably represents the major peak in the occupational history of the region. As such, the available radiocarbon data support as a whole the broad findings of archaeological research from East Texas (see Story 1990b; Middlebrook and Perttula 1997). Other 100 year intervals with large numbers of radiocarbon dates are (in decreasing frequency) A.D. 1001-1100, A.D. 1301-1400, A.D. 1401-1500, and A.D. 901-1000. Radiocarbon dates are particularly rare for the A.D. 1601-1700 and A.D. 1701-1800 intervals.

Again using calibrated ages and mid-points of 1-sigma age ranges, but looking at 25 year intervals, there are interesting fluctuations in the number of radiocarbon dates for the Caddoan period sites in East Texas (Figure 4). The 25 year intervals between A.D. 12011225 and A.D. 1351-1375--the early and late parts of the Middle Caddoan period--have the most radiocarbon dates, followed by the intervals between A.D. 1226-1250 and A.D. 1326-1350.

\section{DISCUSSION}

The single possible radiocarbon date from a Paleoindian context in East Texas is from charcoal in a possible hearth buried in Late Pleistocene alluvium at the Delta Bone Quarry 5 (41DT86) on the North Sulphur River (see Slaughter and Hoover 1963, 1965). While the context of the materials (including an antler tool) from the site are not unequivocal, the calibrated 1 sigma date of $8082-9170$ B.C. is broadly contemporaneous with Clovis, Folsom, and Dalton complexes in the region.

Two sites in East Texas, both in the Sulphur River basin, have archaeological components dated by radiocarbon to pre-3000 B.C. contexts. A single burned rock feature at the Unionville site (41CS151) has a calibrated date of 4040-4161 B.C. (see Cliff et al. 1996), while extensive excavations at the Finley Fan site (41HP159) exposed portions of two buried and stratigraphically discrete Middle Archaic components that date between 3152 4410 B.C. (see Fields et al. 1997:42).

For the Late Archaic period, there are still few well-dated archaeological components, although occupations of this period are apparently abundant throughout all East Texas river valleys and hinterland areas (cf. Fields 1995; Perttula 1995). Fairly well-dated Late Archaic components include buried shell lens that date from 766-1084 B.C. at the Winston site (41HE245) on the Trinity River (see Richner and Bagot 1978); a buried scatter of burned rocks and lithic artifacts at the W. S. Long \#3 site (41HP118) in the South Sulphur River floodplain that dates from 924-1222 B.C. (see McGregor and Martin 1997); and a small concentration of tools and burned rocks at the Mockingbird site (41TT550) that date between 408-828 B.C. (see Table 1).

The best-dated Woodland period components in East Texas were investigated prior to the construction of Cooper Lake on the South Sulphur River (Fields et al. 1997). These include the Tick (41DT6), Spike (41DT16), Hurricane Hill (41HP106), and 41HP137 sites. The Tick and Spike sites have thick $(60-100 \mathrm{~cm})$ middens, with calibrated age spans for the Woodland occupations of A.D. 192-896 and B.C. 195-A.D. 891, respectively (see Table 1). The six calibrated dates from Woodland period contexts at Hurricane Hill range from A.D. 59-449, and they are from features associated with a small midden and a 


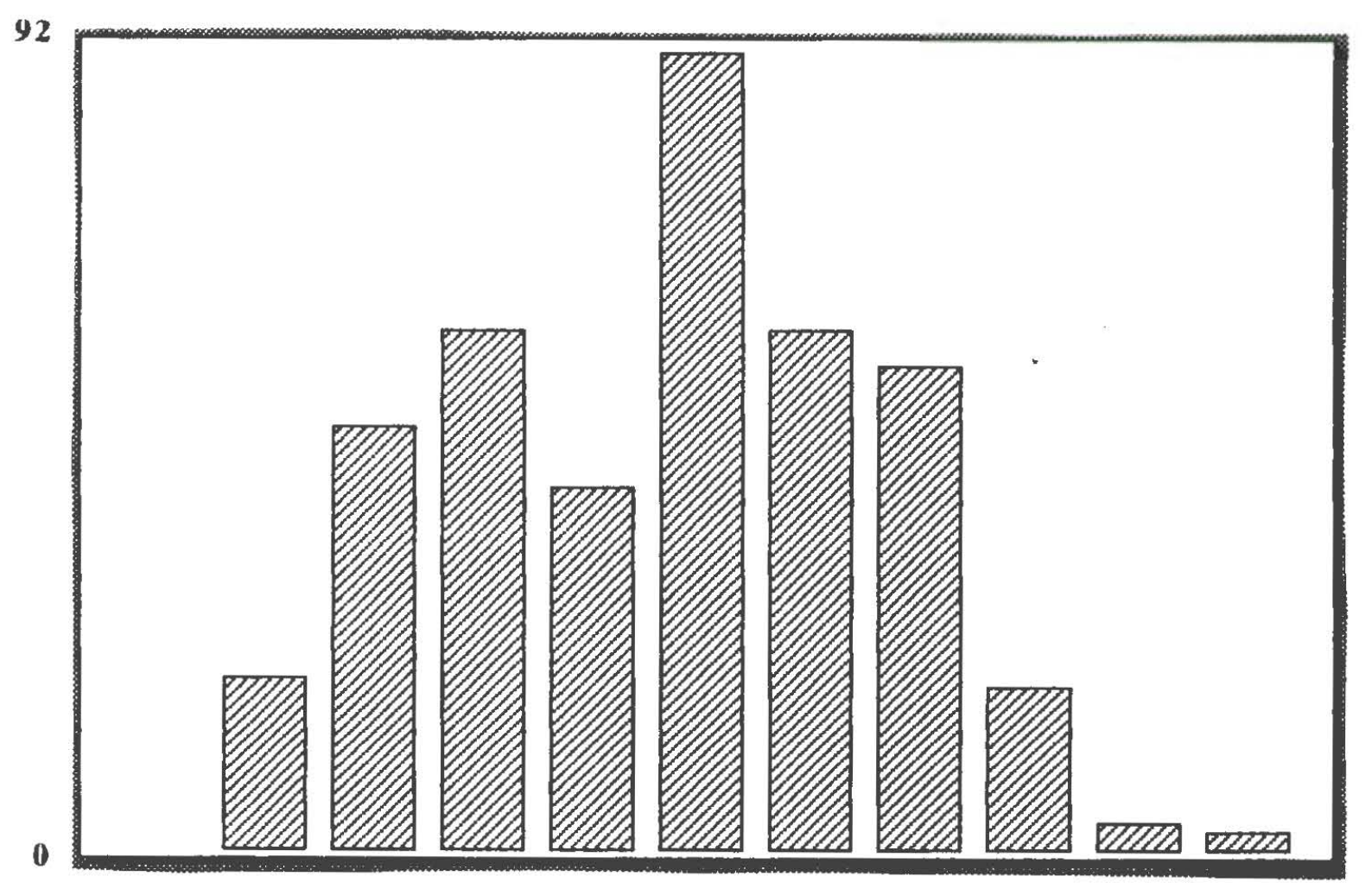

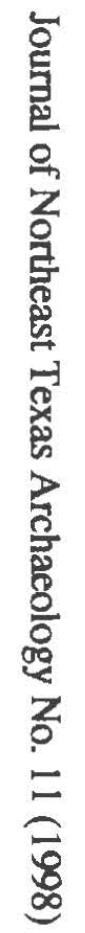

Figure 3. Number of Calibrated Radiocarbon Dates at 100 Year Intervals, A.D. 8001750. 


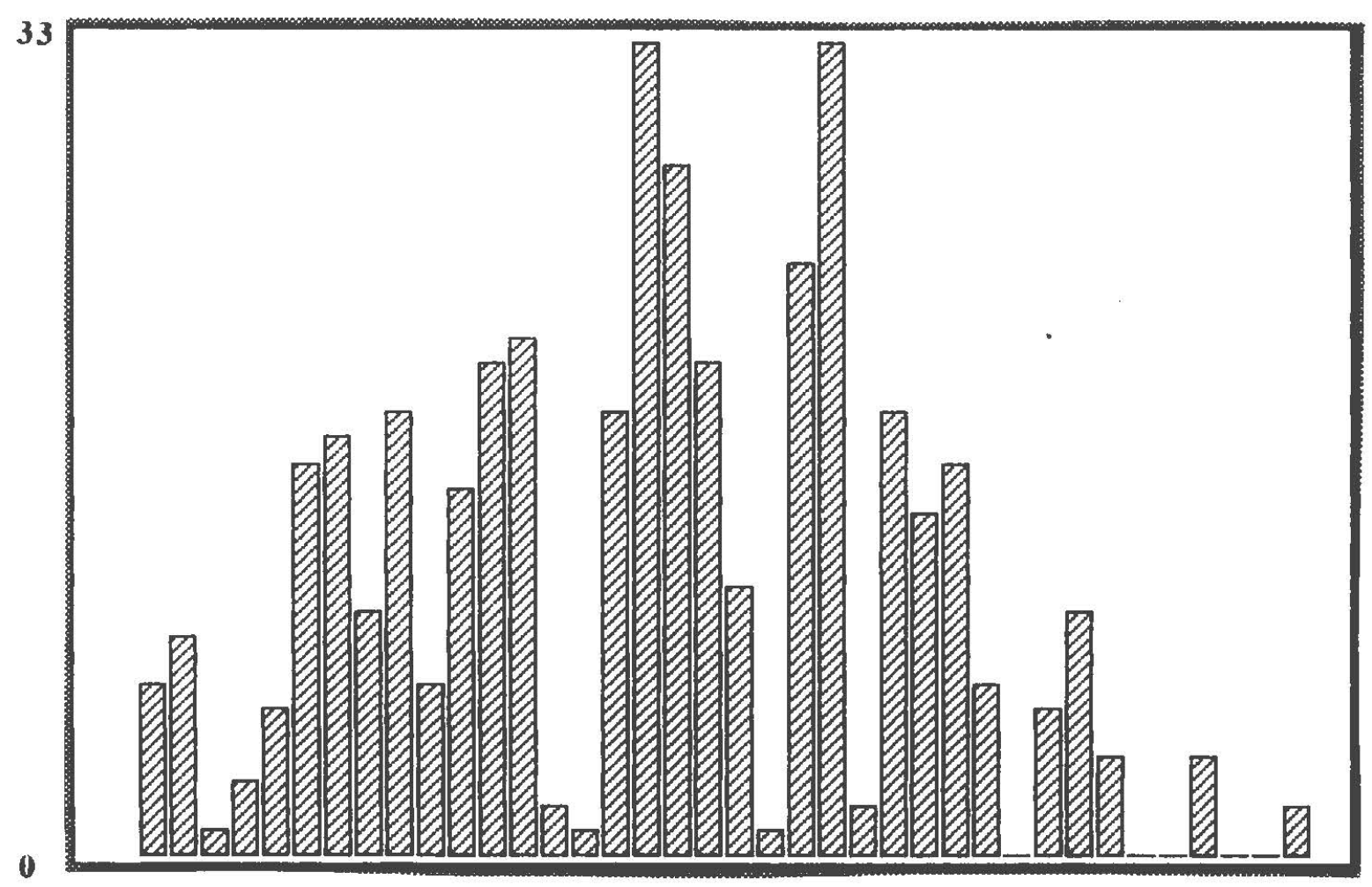

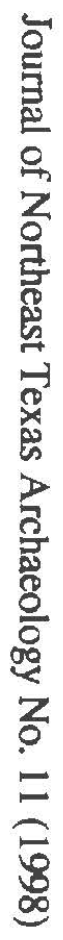

Figure 4. Number of Calibrated Radiocarbon Dates at 25 Year Intervals, A.D. 8001675. 
cemetery of cremations and bundle burials (Perttula 1998). At 41HP137, the Woodland component dates from B.C. 122-A.D. 652, the radiocarbon dates being obtained from small pit features, one of which contained charred cultivated squash seeds (see McGregor 1997).

Certainly the most thoroughly dated Formative and Early Caddoan period site in East Texas is the George C. Davis site (41CE19), a large village and mound center on the Neches River (Story 1997). Calibrated radiocarbon dates from village contexts establish that the site was occupied beginning in the ninth century A.D., and then continuously settled through the end of the 13th century A.D. A late series of calibrated dates from a few village contexts (such as Units 11, 43, and 109; see Story 1998:Table 2-1) suggest that the site was inhabited to some degree as late as ca. A.D. 1350 (see Table 1). While there are fewer dates from the three mounds at George C. Davis, and there are inconsistencies between several of the dates from the same general contexts, it does appear to be the case that Mound A (a large flat-topped platform) and Mound C (a burial mound) were built in the latter part of the Formative Caddoan period (see Story 1997, 1998), and Mound B (flattopped platform) was constructed about A.D. 1200 or slightly earlier.

There are several well-dated Early Caddoan period habitation sites at Cooper Lake, including the upper component at Spike, Doctors Creek (41DT124; see Martin 1997), and 41DT63 (Fields et al. 1997). In the upper Sabine River basin, Early Caddoan habitation sites with consistent radiocarbon dates have been investigated at Taddlock (41WD482) and Spoonbill (41WD109) (see Bruseth and Perttula 1981), as well as the Hudnall-Pirtle (41RK4) mound center and village in the middle stretches of the Sabine River basin (see Bruseth 1991). Two calibrated dates from one of the eight mounds at Hudnall-Pirtle range between A.D. 1152-1250. In the Red River, dated Early Caddoan period components are best known from the Roitsch or Sam Kaufman (41RR16) and Ray (41LR135) sites, both investigated during the 1991-1992 Texas Archeological Society field schools under the direction of Dr. James E. Bruseth. At Roitsch-Sam Kaufman, four calibrated dates from a structure near the East Mound (see Skinner et al. 1969) range between A.D. 982-1250 (see Table 1).

Two of the archaeological sites at Cooper Lake have fairly well-dated components that document settlements that extend from the Early Caddoan period into the Middle Caddoan period, Spider Knoll (41DT11) and Arnold (41HP102). At Spider Knoll, the many dates (see Table 1) suggest the site was used a number of times over a period of ca. 400 years (Fields et al. 1997:61), with the majority of the calibrated dates ranging from A.D. 8801287 (see Table 1). With a few exceptions, the radiocarbon dates from the Arnold site fall into this same calibrated age range.

There are several Middle Caddoan period components in East Texas that appear to be welldated by radiocarbon and/or OCR assays. At site 41TT670 (Largent et al. 1997) on White Oak Creek, one calibrated radiocarbon date and an OCR date (see Table 2) suggest the Middle Caddoan component dates about A.D. 1150-1280, while two radiocarbon dates from Knight's Bluff (41CS14) pertain to a late Middle Caddoan phase that dates from ca. A.D. 1300-1400 (Cliff 1997: Table 1); the OCR dates from the midden. OCR and radiocarbon dates from mound contexts at the Fasken site (41RR14) suggest that Mound B was initially constructed in the 11th century and Mound $C$ in the 12th or early 13th century, during the Sanders phase occupation of this multiple mound center.

A residential Middle Caddoan period component at the Hurricane Hill site (41HP106) in the Cooper Lake area dates from a number of calibrated radiocarbon assays from features on the South rise to between A.D. 1248-1394 (see Perttula 1998b; Fields et al. 1997). An 
archeomagnetic date of A.D. $1300 \pm 50$ has also been obtained from this Middle Caddoan component.

In the middle and upper Sabine River basin, the best dated Middle Caddoan components include McKenzie (41WD55), a substructural mound site (Granberry 1995), the Oak Hill Village (41RK214), and Spoonbill (41WD109) (see Table 1). The calibrated dates from the McKenzie mound range between A.D. 1298-1470, while the three from Middle Caddoan features at the Spoonbill site are slightly earlier (A.D. 1228-1393). The many available radiocarbon dates from the Oak Hill Village suggest the occupation there dates between ca. A.D. 1150-1400, but additional radiocarbon dates on other structures and features, along with the ceramic analyses of the decorated sherds, may well refine the estimates of the site's temporal range (Robert Rogers, 1998 personal communication).

The Washington Square site (41NA49) in the Neches-Angelina river basin is another welldated mound complex (Corbin and Hart 1998). Pooled radiocarbon dates on charcoal, hardwood nutshells, and charred corn range between cal AD 1268-1302 (Corbin and Hart 1998:74 and Table 4). Finally, four calibrated radiocarbon assays from the Tyson site (41SY92) date this important Middle Caddoan period settlement in the Attoyac River basin (Middlebrook 1994) to between A.D. 1336-1490 (see Table 1). One of the dates was on mussel shells included as grave goods with Feature 14, the burial of a 3 to 4 year old child accompanied by many grave goods (Middlebrook 1994:16).

None of the Late Caddoan archaeological phases in East Texas (see Story 1990b:Table 43) are particularly well-dated by either radiocarbon or OCR methods. This is particularly the case for the Frankston and Allen phases, although several late 17th-early 18th century archeomagnetic dates have been obtained from the Allen phase component at the Deshazo site (Story 1995), and two radiocarbon dates from a midden deposit at the Alcoa No. 1 site (41AN87) date the Frankston phase occupation between A.D. 1386-1488 (Amick et al. 1991).

The Titus and McCurtain phases have become better dated by absolute means over the last few years (cf. Perttula et al. 1997a, 1998; Bruseth 1998). For the Titus phase, radiocarbon and OCR dates from sites such as Tuck Carpenter (4ICP5), Sam Roberts (41CP8), Underwood (41CP230), 41TT182, Mockingbird (41TT550), 41TT653, 41UR118 and Rookery Ridge (41UR133) at proposed Lake Gilmer, the Camp Joy Mound (41UR144) at Lake O' the Pines, and Steck (41WD529) suggest that the Titus phase dates between ca. A.D. 1430-1680 (Perttula 1998c). Significantly, four comparable OCR and radiocarbon dates from the same context--a burned house lens--at the Camp Joy Mound (see Tables 1 and 2) have convincingly documented the use of the platform mound at the site between about A.D. 1500-1650.

Radiocarbon dates from McCurtain phase contexts at the Roitsch-Sam Kaufman, Holdeman (41RR11; see Perino 1995), and Rowland Clark (41RR77; Perino 1994) sites indicate that the McCurtain phase can be divided into early (ca. A.D. 1300/1350-1500) and late (ca. A.D. 1500-1700) contexts (cf. Bruseth 1998), with corresponding changes in ceramic decorative styles and the shape of arrow points. The early McCurtain phase features at the Holdeman site date to A.D. 1392-1478 at 1-sigma and A.D. 1332-1513 at Roitsch-Sam Kaufman (see Table 1), while calibrated dates from ceramically-later features at the Rowland Clark site range from A.D. 1502-1603. Interestingly, calibrated radiocarbon dates from the Peerless Bottoms site (41HP175) in the upper Sulphur River basin, having virtually the same variety of Caddoan ceramics as early McCurtain phase sites on the Red River, range between A.D. 1330-1524 (see Fields et al. 1994b). 


\section{SUMMARY}

Given the possibility of sampling biases based on the selective collection of samples from the better preserved sedentary Caddoan occupation of the region, the highly concentrated nature of cultural resource management excavation projects in East Texas (see the discussion in Bruseth [1998:49]), and calibration curve effects (e.g., Miller 1996:55-69) on such a series of calibrated radiocarbon dates, there are clear peaks and valleys in the number of radiocarbon dates from prehistoric archaeological sites in East Texas (see Figures 1 and 2). Most notably, the analysis of the age ranges in the calibrated dates indicate that most pertain to prehistoric and protohistoric Caddoan Indian occupations, particularly the Early (A.D. 1000-1200) through Middle Caddoan (A.D. 1200-1400) periods when prehistoric Caddoan settlements were widely distributed throughout the region. Surely, future analyses of age trends based on a much larger and spatially expansive radiocarbon and OCR data base will help to clarify and enrich these findings.

\section{ACKNOWLEDGMENTS}

I would like to thank the following individuals for providing me with some of the unpublished information on radiocarbon and OCR assays from East Texas sites, namely Robert Rogers, Mark Walters, David Sherman, and David H. Jurney. Thanks also to Douglas S. Frink for conducting the analyses of the OCR samples, and to Victor Galan, Bo Nelson, Dan Prikryl, Mark Parsons, and Jim Bruseth for assistance in collecting new OCR samples from East Texas sites; portions of that effort were funded by the Texas Archeological Society's Donors Fund.

\section{REFERENCES CITED}

Amick, C., E. Furman, T. K. Perttula, J. E. Bruseth, and B. C. Yates

1991 ALCOA\#1 (41AN87): A Frankston Phase Settlement along Mound Prairie Creek, Anderson County, Texas. Caddoan Archeological Newsletter II (No. 2):11-15.

Bruseth, J. E.

1991 Hudnall-Pirtle Site (41RK4): An Early Caddoan Mound Complex in Northeast Texas. Caddoan Archeology Newsletter II (No. 3):9-15.

1998 The Development of Caddoan Polities Along the Middle Red River Valley of Eastern Texas and Oklahoma. In The Native History of the Caddo: Their Place in Southeastern Archaeology and Ethnohistory, edited by T. K. Perttula and J. E. Bruseth, pp. 47-68. Studies in Archeology 30. Texas Archeological Research Laboratory, The University of Texas at Austin.

Bruseth, J. E. and T. K. Perttula

1981 Prehistoric Settlement Patterns at Lake Fork Reservoir. Texas Antiquities Permit Series, Report No. 2. Texas Antiquities Committee, Austin, and Southern Methodist University, Dallas.

Cliff, M. B.

1997 The Middle Caddoan Period in the Lower Sulphur River Area. Journal of Northeast Texas Archaeology No. 9:9-16. 
Cliff, M. B., M. M. Green, S. M. Hunt, D. Shanabrook, and D. E. Peter

1996 Excavations in Area $C$ of the Unionville Site (41CS151), White Oak Creek Mitigation Area (WOCMA), Cass County, Texas. Report of Investigations No. 4, White Oak Creek Mitigation Area Archeological Technical Series. Geo-Marine, Inc., Plano.

Corbin, J. E. and J. P. Hart

1998 The Washington Square Mound Site: A Middle Caddo Mound Complex in South Central East Texas. Bulletin of the Texas Archeological Society 69:47-78.

Cruse, J. B.

1995 Archaeology at the Oak Hill Village: A Caddoan Settlement in Rusk County. Heritage 13(1):10-14.

Doehner, K. and R. E. Larson

1978 Archaeological Research at the Proposed Cooper Lake, Northeast Texas, 19741975. Research Report 108. Archaeology Research Program, Southern Methodist University, Dallas.

Fields, R. C.

1995 The Archeology of the Post Oak Savannah of East-Central Texas. Bulletin of the Texas Archeological Society 66:301-330.

Fields, R. C., E. F. Gadus, L. W. Klement, and K. M. Gardner

1994a Excavations at the Spider Knoll Site, Cooper Lake Project, Delta County, Texas. Reports of Investigations No. 96. Prewitt and Associates, Inc., Austin.

Fields, R. C., E. F. Gadus, and L. W. Klement

1994b The Peerless Bottoms Site: A Late Caddoan Component at Cooper Lake, Hopkins County, Texas. Bulletin of the Texas Archeological Society 65:55-114.

Fields, R. C., M. E. Blake, and K. W. Kibler

1997 Synthesis of the Prehistoric and Historic Archeology of Cooper Lake, Delta and Hopkins Counties, Texas. Reports of Investigations No. 104. Prewitt and Associates, Inc., Austin.

Frink, D. S.

1992 The Chemical Variability of carbonized Organic Matter Through Time. Archaeology of Eastern North America 20:67-79.

1994 The Oxidizable Carbon Ratio (OCR): A Proposed Solution to some of the problems Encountered with Radiocarbon Data. North American Archaeologist 15 (No. 1):1729.

1995 Application of the Oxidizable Carbon Ratio Dating Procedure and Its Implications for Pedogenic Research. In Pedological Perspectives in Archaeological Research, edited by M. E. Collins, pp. 95-106. SSSA Special Publication 44. Soil Science Society of America, Madison, Wisconsin.

Granberry, D.

1995 William T. McKenzie Mound. The Record 46 (No. 1):1-18. Dallas Archeological Society, Dallas. 
Kindall, $\mathbf{S}$.

1997 The Oxidizable Carbon Ratio (OCR) Technique: A New, Low-Cost Dating Method. The Steward, Collected Papers on Texas Archeology 4:91-94. Office of the State Archeologist, Texas Historical Commission, Austin.

Kromer, B. and B. Becker

1993 German Oak and Pine ${ }^{14} \mathrm{C}$ Calibration, 7200-9439 BC. Radiocarbon 35 (No. 1):125-135.

Largent, F. B., D. L. Beene, M. B. Cliff, and S. M. Hunt

1997 Cultural Resources Testing of Two Sites within the White Oak Creek Wildlife Management Area (WOCMA), Bowie and Titus Counties, Texas. White Oak Creek Wildlife Management Area Archeological Technical Series, Report of Investigations No. 6. Geo-Marine, Inc., Plano.

Martin, W. A.

1997 Archaeological Investigations at 41DT124: The Doctors Creek Site. In Archaeological Investigations at Cooper Lake, Delivery Order Numbers 2, 3, \& 4, 1987: Cultural Resource Studies for Cooper Lake, Hopkins and Delta Counties, Texas, by D. E. McGregor, M. M. Green, D. H. Jurney, W. A. Martin, R. W. Moir, and J. W. Saunders, pp. 271-340. 2 Vols. Archaeology Research Program, Department of Anthropology, Southern Methodist University, Dallas.

McGregor, D. E.

1997 Archaeological Investigations at 41HP137. In Archaeological Investigations at Cooper Lake, Delivery Order Numbers 2, 3, \& 4, 1987: Cultural Resource Studies for Cooper Lake, Hopkins and DeltaCounties, Texas, by D. E. McGregor, M. M. Green, D. H. Jurney, W. A. Martin, R. W. Moir, and J. W. Saunders, pp. 341361. 2 Vols. Archaeology Research Program, Department of Anthropology, Southern Methodist University, Dallas.

McGregor, D. E. and W. A. Martin

1997 Site Descriptions of Tested Prehistoric Sites. In Archaeological Investigations at Cooper Lake, Delivery Order Numbers 2, 3, \& 4, 1987: Cultural Resource Studies for Cooper Lake, Hopkins and DeltaCounties, Texas, by D. E. McGregor, M. M. Green, D. H. Jurney, W. A. Martin, R. W. Moir, and J. W. Saunders, pp. 31126. 2 Vols. Archaeology Research Program, Department of Anthropology, Southern Methodist University, Dallas.

Middlebrook, $T$.

1994 An Update of Archaeological Investigations at the Tyson Site (41SY92). Journal of Northeast Texas Archaeology No. 3:1-36.

Middlebrook, T. and T. K. Perttula

1997 The Middle Caddoan Period in East Texas: A Summary of the Findings of the East Texas Caddoan Research Group. Journal of Northeast Texas Archaeology No. 9:18.

Miller, M. R., III

1996 The Chronometric and Relative Chronology Project. Archaeological Technical Report No. 5. Anthropology Research Center, Department of Sociology and Anthropology, University of Texas at El Paso. 
Parsons, M.

1998 41UR133: A Late Caddo Hamlet at Lake Gilmer. Cultural Resource Management News \& Views 10(1):16-19. Division of Antiquities Protection, Texas Historical Commission, Austin.

Perino, G.

1994 Archaeological Research at the Rowland Clark Site (41RR77), Red River County, Texas. Journal of Northeast Texas Archaeology No. 4:3-42.

1995 The Dan Holdeman Site (41RR11), Red River County, Texas. Journal of Northeast Texas Archaeology No. 6:3-65.

Perttula, T. K.

1995 The Archeology of the Pineywoods and Post Oak Savanna of Northeast Texas. Bulletin of the Texas Archeological Society 66:331-359.

1998a A Compendium of Radiocarbon and Oxidizable Carbon Ratio Dates from Archaeological Sites in East Texas, with a Discussion of the Age and Dating of Select Components and Phases. Radiocarbon 39(3), in press.

1998c Late Caddoan Societies in the Northeast Texas Pineywoods. In The Native History of the Caddo: Their Place in Southeastern Archaeology and Ethnohistory, edited by T. K. Perttula and J. E. Bruseth, pp. 69-90. Studies in Archeology 30. Texas Archeological Research Laboratory, The University of Texas at Austin.

Perttula, T. K. (editor)

1998b The Hurricane Hill Site (41HP106): The Archaeology of a Late Archaic/Early Ceramic and Early-Middle Caddoan Settlement in Northeast Texas. Special Publication No. 4. Friends of Northeast Texas Archaeology, Austin and Pittsburg. In preparation.

Perttula, T. K. and D. J. Prikryl

1997 Archeological Survey of Pastures 145A and 147B for the Texas Department of Criminal Justice at the Eastham State Prison Farm, Houston County, Texas. Report of Investigations No. 2. Archeological \& Environmental Consultants, Austin.

Perttula, T. K., M. Turner, and B. Nelson

1997a Radiocarbon and Oxidizable Carbon Ratio Dates from the Camp Joy Mound (41UR 144) in Northeast Texas. Caddoan Archeology 7 (No. 4):10-16.

Perttula, T. K., D. J. Prikryl, and B. Nelson

1997b Archeological Evaluation of a Proposed Sewer Line in the Knight's Bluff Campground at Atlanta State Park, and Delineation of the Knight's Bluff Site (41CS14) Cemetery/Midden Areas. Texas Archeological Research Laboratory, The University of Texas at Austin.

Perttula, T. K., M. Tate, H. Neff, J. W. Cogswell, M. D. Glasscock, E. Skokan, S. Mulholland, R. Rogers, and B. Nelson

1998 Analysis of the Titus Phase Mortuary Assemblage at the Mockingbird or “Kahbakayammaahin" Site (4ITT550). Document No. 970849. Espey, Huston \& Associates, Inc., Austin. 
Ramenofsky, A. F. and A. Steffen

1998 Units as Tools of Measurement. In Unit Issues in Archaeology: Measuring Time, Space, and Material, edited by A. F. Ramenofsky and A. Steffen, pp. 3-17. University of Utah Press, Salt Lake City.

Richner, J. J. and J. T. Bagot (assemblers)

1978 A Reconnaissance Survey of the Trinity River Basin, 1976-1977. Research Report 113. Archaeology Research Program, Southern Methodist University, Dallas.

Skinner, S. A., R. K. Harris, and K. M. Anderson (editors)

1969 Archaeological Investigations at the Sam Kaufman Site, Red River County, Texas. Contributions in Anthropology No. 5. Department of Anthropology, Southem Methodist University, Dallas.

Slaughter, B. H. and B. R. Hoover

1963 Sulphur River Formation and the Pleistocene Mammals of the Ben Franklin Local Fauna. Journal of the Graduate Research Center 31(3):132-148. Southem Methodist University, Dallas.

1965 An Antler Artifact from the Late Pleistocene of Northeastern Texas. American Antiquity 30(3):351-352.

Story, D. A.

1990a Radiocarbon Assays. In The Archeology and Bioarcheology of the Gulf Coastal Plain, by D. A. Story, J. A. Guy, B. A. Burnett, M. D. Freeman, J. C. Rose, D. G. Steele, B. W. Olive, and K. J. Reinhard, pp. 658-735. Research Series No. 38. 2 Vols. Arkansas Archeological Survey, Fayetteville.

1990b Cultural History of the Native Americans. In The Archeology and Bioarcheology of the Gulf Coastal Plain, by D. A. Story, J. A. Guy, B. A. Burnett, M. D. Freeman, J. C. Rose, D. G. Steele, B. W. Olive, and K. J. Reinhard, pp. 163-366. Research Series No. 38. 2 Vols. Arkansas Archeological Survey, Fayetteville.

1995 General Summary and Synthesis. In The Deshazo Site, Nacogdoches County, Texas, Volume 2: Artifacts of Native Manufacture, edited by D. A. Story, pp. 233247. Studies in Archeology 21. Texas Archeological Research Laboratory, The University of Texas at Austin.

1997 1968-1970 Archeological Investigations at the George C. Davis Site, Cherokee County, Texas. Bulletin of the Texas Archeological Society 68:1-110.

1998 The George C. Davis Site Mounds, Structures, and Burials: Glimpses into Early Caddoan Symbolism and Ideology. In The Native History of the Caddo: Their Place in Southeastern Archaeology and Ethnohistory, edited by T. K. Perttula and J. E. Bruseth, pp. 9-43. Studies in Archeology 30. Texas Archeological Research Laboratory, The University of Texas at Austin.

Story, D. A. and S. Valastro, Jr.

1977 Radiocarbon Dating and the George C. Davis Site, Texas. Journal of Field Archaeology 4(1):63-89. 
Stuiver, M. and P. J. Reimer

1993a Extended ${ }^{14} \mathrm{C}$ Data Base and Revised CALIB 3.0 ${ }^{14} \mathrm{C}$ Age Calibration Program. Radiocarbon 35 (No. 1):215-230.

1993b CALIB User's Guide Rev 3.0.3A for Macintosh Computers. Quaternary Research Center, University of Washington, Seattle. 
Table 1. Additional Radiocarbon Dates from East Texas

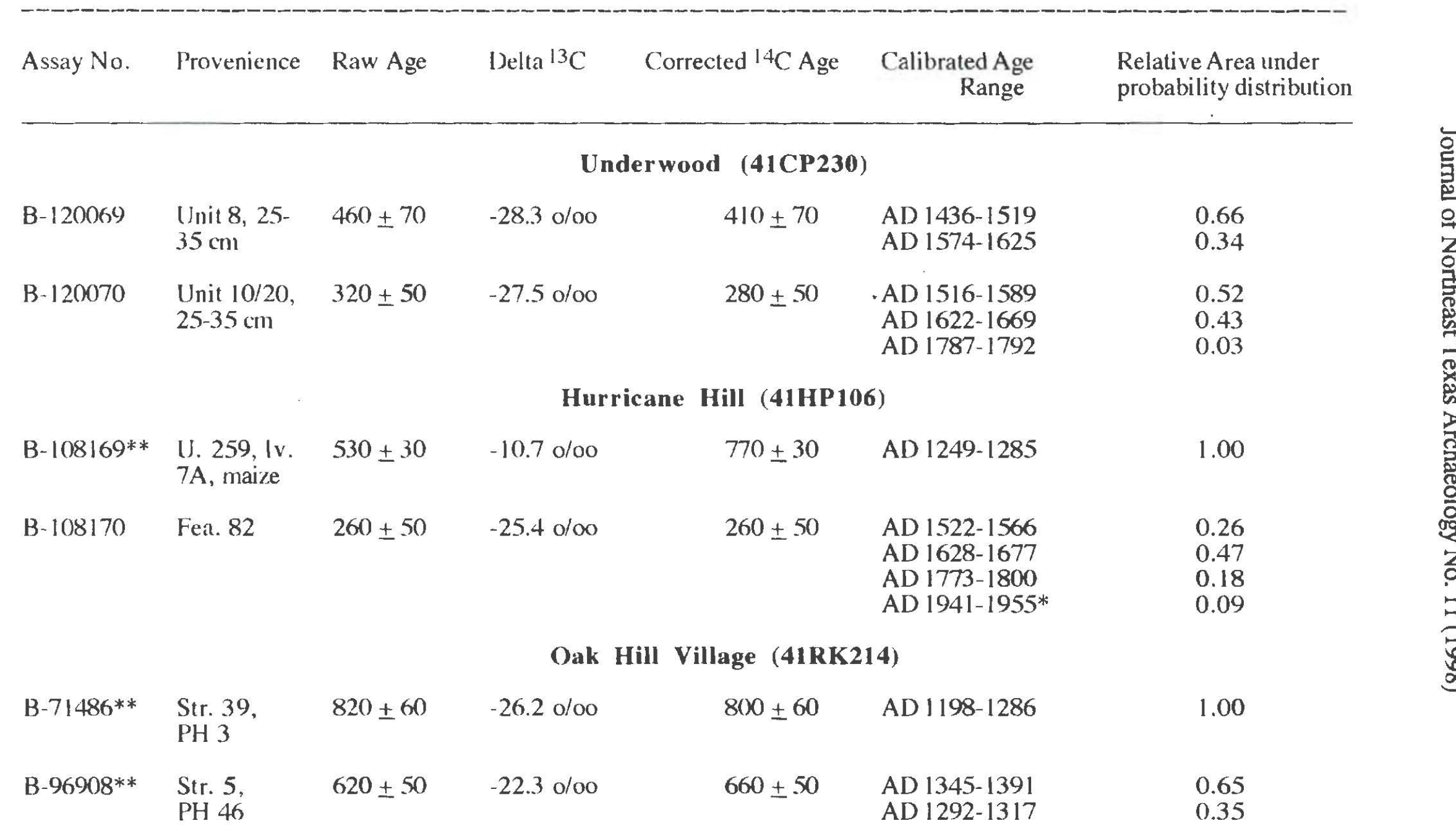




\begin{tabular}{|c|c|c|c|c|c|c|}
\hline Aissay No. & Provenience & Raw Age & Delta ${ }^{13} \mathrm{C}$ & Corrected ${ }^{14} \mathrm{C}$ Age & $\begin{array}{c}\text { Calibrated Age } \\
\text { Range }\end{array}$ & $\begin{array}{l}\text { Relative A rea under } \\
\text { probability distribution }\end{array}$ \\
\hline В $96909 * *$ & $\begin{array}{l}\text { Str. 12?, } \\
\text { PH } 1\end{array}$ & $740 \pm 50$ & $-27.0 \mathrm{o} / \mathrm{oo}$ & $700 \pm 50$ & $\begin{array}{l}\text { AD 1276-1311 } \\
\text { AD 1351-1387 }\end{array}$ & $\begin{array}{l}0.58 \\
0.42\end{array}$ \\
\hline В.96910** & $\begin{array}{l}\text { Str. 2, } \\
\text { PH } 14.5\end{array}$ & $720 \pm 60$ & $-24.5 \mathrm{o} / 00$ & $720 \pm 60$ & $\begin{array}{l}\text { AD 1247- } 1309 \\
\text { AD 1356- } 1383\end{array}$ & $\begin{array}{l}0.76 \\
0.24\end{array}$ \\
\hline B $.96911 * *$ & $\begin{array}{l}\text { Str. } 12 \\
\text { PH } 3\end{array}$ & $700 \pm 50$ & $-24.1 \mathrm{o} / 00$ & $720 \pm 50$ & $\begin{array}{l}\text { AD 1253- } 1307 \\
A D 1361-1378\end{array}$ & $\begin{array}{l}0.85 \\
0.15\end{array}$ \\
\hline В $96912 * *$ & $\begin{array}{l}\text { Str. } 5 \text {, } \\
\text { PH } 45\end{array}$ & $670 \pm 50$ & $-24.9 \mathrm{o} / \infty 0$ & $670 \pm 50$ & $\begin{array}{l}\text { AD 1347- } 1390 \\
\text { AD } 1288-1315\end{array}$ & $\begin{array}{l}0.61 \\
0.39\end{array}$ \\
\hline В $96913^{* *}$ & $\begin{array}{l}\text { Str. 12, } \\
\text { PH 15 }\end{array}$ & $850 \pm 60$ & $-24.5 \mathrm{o} / 00$ & $850 \pm 60$ & $\begin{array}{l}\text { AD 1159- } 1275 \\
\text { AD 1065- } 1074 \\
\text { AD } 1127-1133\end{array}$ & $\begin{array}{l}0.93 \\
0.04 \\
0.03\end{array}$ \\
\hline В.96914** & $\begin{array}{l}\text { Str. } 5 \\
\text { PH } 19\end{array}$ & $710 \pm 60$ & $-23.6 \mathrm{o} / \mathrm{oo}$ & $730 \pm 60$ & $\begin{array}{l}\text { AD 1232- } 1306 \\
\text { AD 1363-1376 }\end{array}$ & $\begin{array}{l}0.90 \\
0.10\end{array}$ \\
\hline В $96915^{* *}$ & $\begin{array}{l}\text { Str. 2, } \\
\text { PH } 72\end{array}$ & $590 \pm 50$ & $-22.5 \mathrm{o} / 0 \mathrm{o}$ & $630 \pm 50$ & $\begin{array}{l}\text { AD 1304-1324 } \\
\text { AD 1337-1370 } \\
\text { AD 1370- } 1394\end{array}$ & $\begin{array}{l}0.27 \\
0.43 \\
0.31\end{array}$ \\
\hline B $96916^{* *}$ & $\begin{array}{l}\text { Str. } 5 \\
\text { PH } 17\end{array}$ & $660 \pm 50$ & $-24.7 \mathrm{o} / \mathrm{oo}$ & $660 \pm 50$ & $\begin{array}{l}\text { AD 1345-1391 } \\
\text { AD 1292-1317 }\end{array}$ & $\begin{array}{l}0.65 \\
0.35\end{array}$ \\
\hline B $96917 * *$ & $\begin{array}{l}\text { Sitr. } 12 \\
\text { PH } 38\end{array}$ & $180 \pm 50$ & $-25.2 \mathrm{o} / \infty \mathrm{o}$ & $180 \pm 50$ & $\begin{array}{l}\text { AD } 1663-1694 \\
\text { AD } 1726-1816 \\
\text { AD 1922-1955* }\end{array}$ & $\begin{array}{l}0.19 \\
0.60 \\
0.21\end{array}$ \\
\hline
\end{tabular}




\begin{tabular}{|c|c|c|c|c|c|c|}
\hline Assay No. & Provenience & Raw Age & Delta ${ }^{13} \mathrm{C}$ & Corrected ${ }^{14} \mathrm{C}$ Age & $\begin{array}{c}\text { Calibrated Age } \\
\text { Range }\end{array}$ & $\begin{array}{l}\text { Relative Area under } \\
\text { probability distribution }\end{array}$ \\
\hline B- $96918^{* *}$ & $\begin{array}{l}\text { Str. } 5 \text {, } \\
\text { PH } 43\end{array}$ & $630 \pm 50$ & $-17.1 \mathrm{o} / \mathrm{oo}$ & $750 \pm 50$ & AD $1239-1296$ & 1.00 \\
\hline B-96919** & $\begin{array}{l}\text { Str. } 5 \text {, } \\
\text { PH } 18\end{array}$ & $730 \pm 50$ & $-22.3 \mathrm{o} / 00$ & $730 \pm 50$ & $\begin{array}{l}\text { AD 1243-1305 } \\
\text { AD 1368- } 1372\end{array}$ & $\begin{array}{l}0.96 \\
0.04\end{array}$ \\
\hline $\mathrm{B}-96920^{* *}$ & $\begin{array}{l}\text { Str. 2, } \\
\text { PH } 115\end{array}$ & $680 \pm 60$ & $-20.9 \mathrm{o} / \mathrm{oo}$ & $740 \pm 60$ & $\begin{array}{l}\text { AD 1226-1304 } \\
\text { AD 1369-1371 }\end{array}$ & $\begin{array}{l}0.98 \\
0.02\end{array}$ \\
\hline B- $96921 * *$ & $\begin{array}{l}\text { Str. 2, } \\
\text { PH } 50\end{array}$ & $570 \pm 50$ & $-22.9 \mathrm{o} / \infty$ & $610 \pm 50$ & $\begin{array}{l}\text { AD 1307-1360 } \\
\text { AD 1379-1400 }\end{array}$ & $\begin{array}{l}0.71 \\
0.29\end{array}$ \\
\hline B-107399** & $\begin{array}{l}\text { Str. 19, } \\
\text { Fea. } 274\end{array}$ & $520 \pm 50$ & $-26.2 \mathrm{o} / 00$ & $500 \pm 50$ & AD 1403-1448 & 1.00 \\
\hline B- $107400^{* *}$ & $\begin{array}{l}\text { Str. 10, } \\
\text { Fea. } 163\end{array}$ & $480 \pm 50$ & $-28.5 \mathrm{o} / 00$ & $420 \pm 50$ & $\begin{array}{l}\text { AD 1435-1512 } \\
\text { AD 1597-1618 }\end{array}$ & $\begin{array}{l}0.84 \\
0.16\end{array}$ \\
\hline B- $107401^{* *}$ & $\begin{array}{l}\text { Str. 21, } \\
\text { Fea. } 272\end{array}$ & $1180 \pm 70$ & -30.8 o/oo & $1080 \pm 70$ & AD 893-1017 & 1.00 \\
\hline B- $107402 * *$ & $\begin{array}{l}\text { Str. } 35 \\
\text { Fea. } 265\end{array}$ & $1130 \pm 50$ & $-18.4 \mathrm{o} / \mathrm{oo}$ & $1240 \pm 50$ & $\begin{array}{l}\text { AD 763-875 } \\
A D 717-741\end{array}$ & $\begin{array}{l}0.83 \\
0.17\end{array}$ \\
\hline B- $110061 * *$ & $\begin{array}{l}\text { Str. } 38, \\
\text { Fea. } 243, \\
\text { maize }\end{array}$ & $440 \pm 40$ & $-13.2 \mathrm{o} / \mathrm{oo}$ & $640 \pm 40$ & $\begin{array}{l}\text { AD 1343-1392 } \\
\text { AD 1301-1319 }\end{array}$ & $\begin{array}{l}0.74 \\
0.26\end{array}$ \\
\hline
\end{tabular}




\begin{tabular}{|c|c|c|c|c|c|c|}
\hline Assay No. & Provenience & Raw Age & Delta ${ }^{13} \mathrm{C}$ & Corrected ${ }^{14} \mathrm{C}$ Age & $\begin{array}{c}\text { Calibrated Age } \\
\text { Range }\end{array}$ & $\begin{array}{l}\text { Relative Area under } \\
\text { probability distribution }\end{array}$ \\
\hline B-1 $10062^{* *}$ & $\begin{array}{l}\text { Str. } 10, \\
\text { Fea. } 180\end{array}$ & $630 \pm 40$ & $-23.6 \mathrm{o} / 00$ & $650 \pm 40$ & $\begin{array}{l}\text { AD 1345-1391 } \\
\text { AD 1297-1317 }\end{array}$ & $\begin{array}{l}0.71 \\
0.29\end{array}$ \\
\hline B-1 10063** & Fea. 219 & $870 \pm 40$ & $-23.1 \mathrm{o} / 00$ & $900 \pm 40$ & $\begin{array}{l}\text { AD 1049-1090 } \\
\text { AD } 1118-1141 \\
\text { AD } 1155-1209\end{array}$ & $\begin{array}{l}0.35 \\
0.19 \\
0.46\end{array}$ \\
\hline B-110064** & $\begin{array}{l}\text { Fea. 194, } \\
\text { maize }\end{array}$ & $330 \pm 40$ & $-10.3 \mathrm{o} / 00$ & $570 \pm 40$ & $\begin{array}{l}\text { AD 1390-1421 } \\
\text { AD 1315-1347 }\end{array}$ & $\begin{array}{l}0.53 \\
0.47\end{array}$ \\
\hline B-1 $10065^{* *}$ & $\begin{array}{l}\text { Fea. } 105 \\
\text { maize }\end{array}$ & $390 \pm 40$ & $-9.90 / 00$ & $630 \pm 40$ & $\begin{array}{l}\text { AD } 1305-1322 \\
\text { AD } 1339-1368 \\
A D 1372-1393\end{array}$ & $\begin{array}{l}0.26 \\
0.42 \\
0.32\end{array}$ \\
\hline B-110066** & $\begin{array}{l}\text { Str. } 21, \\
\text { Fea. } 173, \\
\text { maize }\end{array}$ & $330 \pm 40$ & $-9.7 \mathrm{o} / 00$ & $570 \pm 40$ & $\begin{array}{l}\text { AD } 1390-1421 \\
\text { AD } 1315-1347\end{array}$ & $\begin{array}{l}0.53 \\
0.47\end{array}$ \\
\hline B- $110067^{* *}$ & $\begin{array}{l}\text { Str. } 19 \\
\text { Fea. } 178, \\
\text { maize }\end{array}$ & $210 \pm 40$ & $-9.5 \mathrm{o} / 00$ & $570 \pm 40$ & $\begin{array}{l}\text { AD } 1390-1421 \\
A D 1315-1347\end{array}$ & $\begin{array}{l}0.53 \\
0.47\end{array}$ \\
\hline B-110068** & $\begin{array}{l}\text { Str. } 39 \\
\text { Fea. } 261\end{array}$ & $590 \pm 40$ & $-26.7 \mathrm{o} / 00$ & $570 \pm 40$ & $\begin{array}{l}\text { AD 1390-1421 } \\
\text { AD 1315-1347 }\end{array}$ & $\begin{array}{l}0.53 \\
0.47\end{array}$ \\
\hline
\end{tabular}




Assay No. Provenience Raw Age Delta ${ }^{13} \mathrm{C} \quad$ Corrected ${ }^{14} \mathrm{C}$ Age $\quad \begin{gathered}\text { Calibrated Age } \\ \text { Range }\end{gathered} \begin{aligned} & \text { Relative Area under } \\ & \text { probability distribution }\end{aligned}$

\section{RK342}

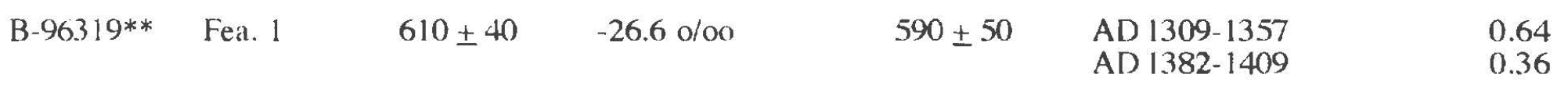

\section{Bryan Hardy (41SM55)}

$650 \pm 40$

AD 1345-1391

0.71

AD 1297-1317

0.29

\section{TT653}

\begin{tabular}{|c|c|c|c|}
\hline B- $105530^{* *}$ & Fea. 3 & $380 \pm 50$ & $-23.8 \mathrm{o} / 00$ \\
\hline B- $1055.51 * *$ & Fea. 3 & $360+50$ & $-21.8 \mathrm{o} / 00$ \\
\hline
\end{tabular}

$\begin{array}{ll}400 \pm 50 & \text { AD } 1442-1519 \\ & \text { AD } 1574-1625 \\ 410 \pm 50 & \text { AD } 1436-1518 \\ & \text { AD } 1580-1624\end{array}$

0.63

0.37

0.69

0.31

\footnotetext{
* Calibrated dates ending in $195.5 *$ denote the influence of atomic bomb C- 14

** Accelerator Mass Spectrometer assays

-• Two-sigma calibrated ages
}

Note: Radiocarbon assays with Delta ${ }^{13} \mathrm{C}$ are corrected (for isotopic fractionation) and calibrated at a 20 -year interval scale for calendric dates using CALIB 3.03c, Test 10 (Stuiver and Reimer 1993a, 1993b). 
Table 2. New Oxidizable Carbon Ratio Dates from East Texas Sites

\begin{tabular}{|c|c|c|c|c|}
\hline Assay No. & Provenience & Calculated OCR Date* & Confidence Interval & Rounded Date \\
\hline \multicolumn{5}{|c|}{ Underwood (41CP230) } \\
\hline ACТ 3215 & $\begin{array}{l}\text { Midden, TU } 3 \text {, } \\
16-18 \mathrm{~cm}\end{array}$ & 458 & \pm 13 & AD 1475-1505 \\
\hline ACT 3216 & $\begin{array}{l}\text { Base of Midden } \\
\text { profile }\end{array}$ & 550 & \pm 16 & AD 1385- 1415 \\
\hline АСТ 3217 & $\begin{array}{l}\text { Middle Depths of } \\
\text { Midden profile }\end{array}$ & 476 & \pm 14 & AD $1455-1490$ \\
\hline \multicolumn{5}{|c|}{$41 \mathrm{HO54}$} \\
\hline ACT 2740 & $\mathrm{SSI}, 15.17 \mathrm{~cm}$ & 3323 & + & 1370 B.C. \\
\hline \multicolumn{5}{|c|}{ Hargrove Lake (41HO150) } \\
\hline АСТ 2743 & $\mathrm{SS} 1,8-10 \mathrm{~cm}$ & 888 & + & AD 1060 \\
\hline \multicolumn{5}{|c|}{$41 \mathrm{HO} 184$} \\
\hline ACT 2899 & BHT $3,26 \mathrm{~cm}$ & 1148 & + & AD 800 \\
\hline AC"T 2900 & $\mathrm{BHT} 3,44 \mathrm{~cm}$ & 1585 & + & AD 360 \\
\hline
\end{tabular}




\begin{tabular}{|c|c|c|c|c|}
\hline Assay No. & Provenience & lated OCR Date* & Confidence Interval & Rounded Date \\
\hline & \multicolumn{4}{|c|}{$41 H S 407$} \\
\hline \multirow[t]{2}{*}{ ACT 3218} & $\begin{array}{l}\text { Associated with Fea. } 1 \\
\text { ST D-38, } 24-28 \mathrm{~cm}\end{array}$ & 602 & \pm 18 & AD $1330-1370$ \\
\hline & \multicolumn{4}{|c|}{ Tom Moore (41PN149) } \\
\hline \multirow[t]{2}{*}{ ACT 2826} & $\begin{array}{l}\text { Base of midden, } \\
40 \mathrm{~cm}\end{array}$ & 1655 & \pm 49 & AD 250-340 \\
\hline & \multicolumn{4}{|c|}{ Fasken (41RR14) } \\
\hline AC. 3261 & $\begin{array}{l}\text { Mound C, N690 } \\
\text { E451, } 42 \mathrm{~cm} \text { bs }\end{array}$ & 682 & \pm 20 & AD $1250-1290$ \\
\hline ACT 3262 & $\begin{array}{l}\text { Mound B, Trench } \\
2, \text { N512E500, Fea. } \\
3 \text { clay floor }\end{array}$ & 808 & \pm 24 & AD $1116-1164$ \\
\hline ACT 3263 & $\begin{array}{l}\text { Mound B, Trench } 2 \text {, } \\
\text { N512E500, Zone } 6 \text {, } \\
163-168 \mathrm{~cm} \text { bs, buried } \\
\text { A-horizon below mound }\end{array}$ & 1011 & \pm 30 & AD 910-970 \\
\hline ACT 3303 & $\begin{array}{l}\text { Mound B, Trench } 2 \text {, } \\
\text { Zone } 5,110-117 \mathrm{~cm} \text { bs, } \\
\text { first mound fill }\end{array}$ & 1175 & \pm 35 & AD 740-810 \\
\hline
\end{tabular}




\begin{tabular}{|c|c|c|c|c|}
\hline Assay No. & Provenience & Calculated OCR Date* & Confidence Interval & Rounded Date \\
\hline \multirow{3}{*}{ ACT 2827} & \multicolumn{4}{|c|}{ Redwine (41SM193) } \\
\hline & Fea. $4,30-40 \mathrm{~cm}$ & 1398 & \pm 41 & AD $510-590$ \\
\hline & & $41 \mathrm{~T}$ & & \\
\hline \multirow[t]{2}{*}{ АCT 2747} & $\mathrm{SS} 1,15-17 \mathrm{~cm}$ & 1753 & + & $\mathrm{AD} 200$ \\
\hline & \multicolumn{4}{|c|}{$41 \mathrm{TN} 113$} \\
\hline \multirow[t]{2}{*}{ ACT 2751} & $\mathrm{STP} 3,15-17 \mathrm{~cm}$ & 1460 & + & AD 490 \\
\hline & \multicolumn{4}{|c|}{41 TT 653} \\
\hline ACT 3264 & $\begin{array}{l}\text { Fea. } 33,60-65 \mathrm{~cm} \\
\text { Str. } 1 \text { hearth }\end{array}$ & 372 & \pm 11 & AD $1570-1590$ \\
\hline ACT 3265 & Fea. $1,30-40 \mathrm{~cm}$ & 140 & \pm 5 & AD $1805-1815$ \\
\hline ACT 3266 & Fea. $1,50-60 \mathrm{~cm}$ & 357 & \pm 10 & AD $1580-1600$ \\
\hline ACT 3267 & $\begin{array}{l}\text { Fea. } 34,30-40 \mathrm{~cm} \text {, } \\
\text { Sir. } 3 \text { midden }\end{array}$ & 230 & \pm 6 & AD $1710-1730$ \\
\hline AC.T 3268 & $\begin{array}{l}\text { Fea. } 34,15-30 \mathrm{~cm} \text {, } \\
\text { Str. } 3 \text { midden }\end{array}$ & 330 & \pm 9 & AD $1610-1630$ \\
\hline
\end{tabular}




\begin{tabular}{|c|c|c|c|c|}
\hline Assay No. & Provenience & Calculated OCR Date* & Confidence Interval & Rounded Date \\
\hline \multicolumn{5}{|c|}{ Rookery Ridge (41UR133) } \\
\hline ACT 3219 & $\begin{array}{l}\text { Saddle Area Profile, } \\
32 \mathrm{~cm} \text {, associated with } \\
\text { clay hearth }\end{array}$ & 757 & \pm 22 & $\mathrm{AD} 1170-1210$ \\
\hline ACT 3220 & $\begin{array}{l}\text { N183EA02, Zone A, } \\
\text { top of midden }\end{array}$ & 319 & \pm 9 & AD $1620-1640$ \\
\hline ACT 3221 & $\begin{array}{l}\text { N183EA02, Zone B, } \\
\text { ash lens }\end{array}$ & 291 & \pm 8 & AD $1650-1670$ \\
\hline ACT 3222 & $\begin{array}{l}\text { N186E391, midden, } \\
39 \mathrm{~cm}\end{array}$ & 547 & \pm 16 & AD $1385-1415$ \\
\hline ACT 3223 & $\begin{array}{l}\mathrm{N} 186 \mathrm{E} 391 \text {, midden, } \\
58 \mathrm{~cm}\end{array}$ & 766 & \pm 22 & AD $1160-1200$ \\
\hline
\end{tabular}

